\title{
Podiform Chromitites: Their composition, origin and environment of formation
}

\author{
1. Centre for Marine Geology. Dalhousie University. Halifax, Nova Scotia B3H 3J5 Canada \\ 2. Department of Earth Sacnces, The University of Hong Kong. Pokfulam Rd.. Hong Kong, China \\ 3. Institute of Geology. Chinese Academy of Geological Sciences, 26 Bainamzhang Rd, Beijing 100037 , China
}

Podiform chromitities are nornmally either high-Cr or high-Al in composition and typically only one type occurs in any given ophiolite. Despite some superficial similarities, high-Cr and high-Al chromitities differ significantly in mineral and bulk-rock geochemistry. Many podiform bodies have been deformed and recrystallized by continued mantle flow but their magmatic origin is widely accepted. We suggest that podiform chromitities occur in the upper parts of ophiolitic or island arc mantle and are formed by reaction between rising melts and the host peridotites. High-Cr and high-Al ores are sightly different in their environment of formation.

\section{Introduction}

Chromitite orebodies occur in two distinct forms: stratiform and podiform. Stratiform bodies are areally extensive layers or bands in matic layered intrusions. Their mineralogies and textures leave little doubt that they crystallized from mafic magmas probably by mixing of evolved and more primitive melts (Irvine. 1977). Classic examples of stratiform chromitites include those in the Muskox. Stillwater and Bushveld layered intrusions.

Podiform chromitites, on the other hand. typically occur as lenticular or pod-shaped bodies. a few meters or tens of meters in length. which are hosted in depleted peridotites of presumed mantle origin. These bodies are individually small but, where abundant. they form large-scale chromitite deposits. The origin and tectonic environment of formation of these deposits have been topics of investigation for many years. Although some features of podiform chromitites remain enigmatic, recent work suggests that they form by melt-rock reaction as mafic magmas pass through, or are ponded in, segments of the upper mantle and that their compositions reflect varying degrees of partial melting of the parental peridotites.

\section{Petrography of podiform chromitites}

Podiform chromitites are typically lens-shaped although many occur as tabular or pencil-like bodies. Many bodies are concordant or subconcordant to the foliation in the surrounding peridotites and exhibit fabrics interpreted to be the result of solid-state flow and recrystallization at relatively high temperatures (Cassard et al., 1981). Most podiform chromitites are hosted in depleted harzburgite, although some occur in Cpx-bearing harzburgite or lherzolite.

Most podiform chromitites, whether hosted in harzburgite or lherzolite, are enclosed in dunite pods or have dunite envelopes several centimeters to a meter thick (Thayer, 1964; Thayer, 1969; Leblanc, 1987; Zhou et al., 1996). These dunite envelopes grade outward into the surrounding harzburgite or therzolite with increasing modal proportions of pyroxene. Where lherzolite is the host, a band of harzburgite typically lies between the lherzolite and the dunite.

Massive, disseminated, nodular and breceiated chromitites are the most common textural types (Figure $1_{\mathrm{A}-\mathrm{D}}$, see inside back cover) and these commonly grade into each other. Massive chromitites typically have shatp contacts with the enclosing dunite whereas disseminated bodies grade outward into the surrounding rock, in some cases passing into interlayered chromitite and dunite.

Massive chromitites are typically coarse-grained rocks composed of more than 80 volume \% chromite. Individual chromite grains are mostly 1 to $5 \mathrm{~mm}$ across (some are up to $30 \mathrm{~mm}$ ), anhedral in shape, and show the effects of corrosion or reaction in addition to mechanical disruption. Textural relationships suggest that the coarse size of most massive chromitites is a primary magmatic feature and not due to recrystallization. The chromite grains are closely packed, leaving very narrow interstices filled with silicate minerals (Thayer, 1964; Greenbaum, 1977).

Disseminated chromitites consist of 25-80 volume \% chromite grains, more or less uniformly scattered in the host silicates (mainly olivine and orthopyroxene) (Figure $l_{C-D}$ ). Individual chromite grains are generally smaller $(0.5-2 \mathrm{~mm})$ and more regular than in the massive varieties. Many disseminated chromitites grade into massive bodies with increasing chromite contents and larger crystal sizes.

Nodular varieties consist of small $(0.3$ to $2.5 \mathrm{~cm})$, spherical or elliptical aggregates of chromite in an olivine-rich matrix that may itself have disseminated chromite (Figure $l_{C-D}$ ). In some cases, individual nodules may be crudely oriented parallel to their long axis. Closely associated with nodular chromitites are orbicular types which have a solid, nodule-like nucleus of chromite surrounded by a mantle of olivine and an outermost rim of fine-grained chromite plus olivine. Both types can grade into massive chromitites with increasing amounts of chromite.

Banded chromitites, with rhythmically alternating chromiterich and olivine-rich layers, are present in many chromitite pods. Such banding usually parallels the long axes of the chromitite pods or lenses, which in turn may parallel the foliation in the host peridotites. Many bands show small-scale folding, faulting and cataclasis. In brecciated chromitites disseminated chromite typically fills spaces between dunite fragments (Figure $1_{D}$ ).

Olivine (Fo 92-97) is the most common matrix mineral, although many chromitites have small amounts of orthopyroxene (En 94-96) and clinopyroxene. In some cases, olivine and orthopyroxene are partly to completely replaced by serpentine, and cracks and veinlets are filled with carbonate and garnet.

Inclusions of olivine, clinopyroxene, orthopyroxene, albite, Fe$\mathrm{Ni}$ alloy and sulfides are present in many chromite grains (e.g., Lorand and Ceuleneer, 1989). In addition, chromites in several bodies, such as those in Al Ays of Saudi Arabia, Troodos in Cyprus, New Caledonia, and Oman (Johan et al., 1983; McElduff and Stumpfl, 1991), contain volatile- and alkali-rich mineral and fluid inclusions. The presence of volatiles can also be deduced from the occurrence of pegmatitic chromitites and associated pegmatitic gabbro and troctolite. The abundance of fluid inclusions and hydrous 


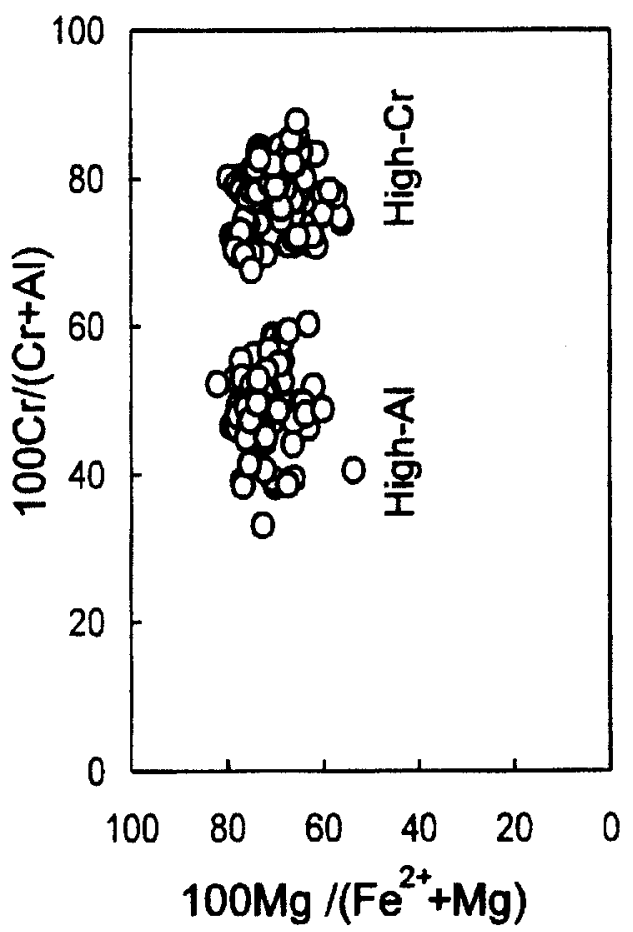

Figure 2 Cr\# versus Mg\# for podiform chromites. High-Alchromitites have Cr\#s of 60 or less whereas high Cr-varietites have Cr\#s of 70 or higher. Data are from Luobusa, Donqiao, Sartohay, Hegenshan Solon, Yushi and and Hongguleleng ophiolites of China.

minerals in chromite grains indicates relatively high water content in the parental magma which, in turn, suggests formation in a suprasubduction zone environment. In such an environment $\mathrm{H}_{2} \mathrm{O}, \mathrm{K}_{2} \mathrm{O}$ rich fluids, and possibly silicate melts derived from the subducted slab can be added to the overlying mantle wedge (Ringwood, 1974; Pearce et al., 1984: Roberts, 1988).

Typically, many of the silicate minerals, particularly olivine and pyroxene, are too magnesian to have crystallized from a melt and probably owe their composition to $\mathrm{Mg}-\mathrm{Fe}$ subsolidus exchang between silicates and chromite (Irvine, 1967; Roeder et al., 1979; Lehmann, 1983)

Table I A comparison of high-Cr and high-Al chromitites from the Luobusa and Sartohay ophiolites of Chian (after Zhou and Robinson, 1994)

\begin{tabular}{|c|c|c|}
\hline & $\mathrm{High}-\mathrm{Cr}$ & High-Al \\
\hline \multirow[t]{2}{*}{ Chromitite } & $\mathrm{Cr} \#>70$ & $\mathrm{Cr} \#<60$ \\
\hline & $\mathrm{TiO}_{2}<0.2 w \mathrm{t} . \%$ & $\mathrm{TiO}_{2}>0.2 \mathrm{wt} . \%$ \\
\hline \multirow[t]{5}{*}{ Peridotite } & Harzburgite & Lherzolite \\
\hline & $\mathrm{TiO}_{2}<0.05$ wt. $\%$ & $\mathrm{TiO}_{2}>0.8 \mathrm{wt} . \%$ \\
\hline & $\mathrm{MgO}=42-51 \mathrm{wt} \%$ & $\mathrm{MgO}=36-48 \mathrm{wt} . \%$ \\
\hline & $\mathrm{Ca}=0-1.5$ wt. $\%$ & $\mathrm{Ca}=0-3.4$ wt. $\%$ \\
\hline & $\mathrm{Al}=0.01-1.20 \mathrm{wt} . \%$ & $\mathrm{Al}=0.3-2.20 \mathrm{wt} . \%$ \\
\hline \multicolumn{3}{|l|}{ Mineral chemistry } \\
\hline Olivine (Fo) & $90-93$ & $86-91$ \\
\hline Opx $\quad($ En $)$ & $91-92$ & $87-88$ \\
\hline$\left(\mathrm{Al}_{2} \mathrm{O}_{3}\right)$ & $0.71-4.13$ wt. $\%$ & $2.29-5.98$ wt. $\%$ \\
\hline$(\mathrm{CaO})$ & $0.48-1.54$ wt. $\%$ & $0.92-4.34 \mathrm{wt} . \%$ \\
\hline \multirow{2}{*}{$\begin{array}{l}(\mathrm{En}) \\
\left(\mathrm{Al}_{2} \mathrm{O}_{3}\right)\end{array}$} & $47-53$ & $43-51$ \\
\hline & $2.75-4.72$ wt. $\%$ & $2.21-7.68$ wt. $\%$ \\
\hline
\end{tabular}

\section{Chromite compositions and parental magmas}

Podiform chromitites are normally either high-Cr or high- $\mathrm{Al}$ in composition (Figure 2) and typically only one type occurs in any given ophiolite. In a few cases, such as the Zambales ophiolite of the Philippines, both high-Cr and high-Al varieties are present but they occur in two distinct lithologic associations and are believed to have crystallized from two compositionally distinct parental magmas (Hock et al., 1986; Yumul, 1992; Yumul and Balce, 1994).

Despite some superficial similarities, high-Cr and high-Al chromitites differ significantly in mineral and bulk-rock geochemistry (Table 1). High-Cr chromitites are characterized by $\mathrm{Cr} \# \mathbf{s}$ $\left(100 \mathrm{Cr} /(\mathrm{Cr}+\mathrm{Al})\right.$ greater than 70 , by very low bulk rock $\mathrm{TiO}_{2}$ and by highly magnesium olivine and orthopyroxene. These chromitites are typically hosted in highly depleted harzburgites (Table I).

High-Al varieties, on the other hand, have Cr\#s less than 60 , have higher bulk-rock $\mathrm{TiO}_{2}$ and less magnesian silicate minerals. The high-Al chromitites are typically hosted in less depleted Cpxbearing harzburgites or lherzolites. Both types have similar shaped chondrite-normalized PGE patterns, enriched in Os, Ir, and $\mathrm{Ru}$ relative to Rh, Pt, and Pd (Zhou and Robinson, 1994). However, high$\mathrm{Cr}$ varieties typically have somewhat higher $\mathrm{Ir}$. $\mathrm{Ru}$, and $\mathrm{Rh}$ contents than high-Al varieties (e.g. Zhou and Robinson, 1994).

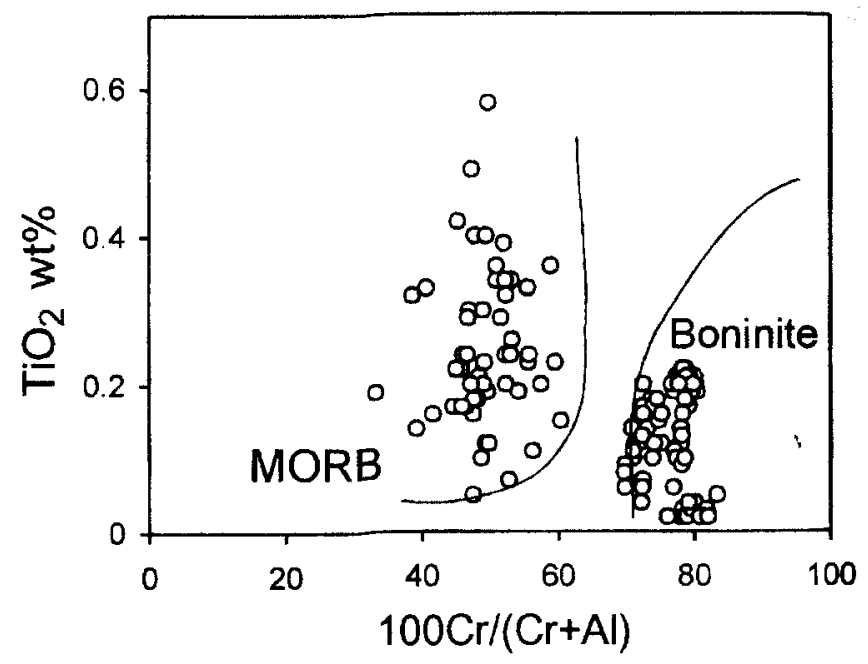

Figure $3 \mathrm{TiO}_{2}$ versus $\mathrm{Cr}$ \# of high-Cr and high-Al podiform chromitites. MORB and boninite fields are from Arai (1992). Data sources are the same as in Figure 2.

Experimental studies have shown that in peridotites, the degree of depletion can be related to the degree of partial melting that the rock has undergone. As the degree of melting increases, the residual minerals become depleted in Fe, $\mathrm{Al}, \mathrm{Ca}$, and Ti, the $\mathrm{Mg \# s}$ of residual olivine and orthopyroxene increase, and the $\mathrm{Al}_{2} \mathrm{O}_{3}$ content of orthopyroxene decreases (Mysen and Kushiro, 1977; Jaques and Green, 1980; Michael and Bonatti, 1985).

Variations in the chrome content of accessory and ore-forming chromite also are believed to be related to the degree of partial melting with $\mathrm{Cr} \#$ s increasing with increasing degrees of melting (Irvine, 1967; Arai, 1980; Dick and Bullen, 1984). Typically, high-Al chromitites plot in the MORB field whereas high-Cr varieties plot in the boninitic field (Figure 3) (Arai, 1992; Zhou and Robinson, 1994). Thus, high-Cr chromitites, hosted in highly depleted harzburgites, are believed to have crystallized from boninitic melts formed by relatively high degrees of partial melting whereas high-Al varieties, hosted in less depleted Cpx-bearing harzburgite and therzolite, are believed to crystallize from tholeiitic melts formed by lower degrees of melting (Roberts, 1992). This does not mean that the mantle sections from which the melts were derived were the same composition 
originally or that the differences in mineral chemistry are caused entirely by the most recent episode of partial melting. The same degree of depletion and the same chromite compositions could be achieved by recycling mantle sections that had undergone several episodes of partial melting (Zhou and Robinson, 1994).

\section{Origin of podiform chromitites}

Textural and mineralogical evidence indicate that podiform chromitites form by crystallization of mafic magmas in the upper mantle (Brown, 1980; Cassard, et. al., 1981; Lago et al., 1982). Cumulate textures, cyclical layering, and silicate gangue minerals are all evidence of a magmatic origin and current models assume formation in magmatic conduits cutting the mantle peridotites (e.g., Leblanc and Ceuleneer, 1992). Many podiform bodies have been deformed and recrystallized by continued mantle flow but their magmatic origin is widely accepted.

What is not so well understood is the mechanism by which chromite is precipitated. Upper mantle melts are generally basaltic in composition and it is not clear how chromite, as a minor component of such melts, can be concentrated to form massive or disseminated deposits. To form monomineralic layers or pods, chromite must have crystallized alone for a period of time and/or have been concentrated by physical processes. Likewise, it is not clear why chromitites are abundant in some mantle sections and totally absent in others (Roberts, 1988).

Johan et al. (1983) and Auge (1987) suggested that chromium can be extracted from magmas by a fluid phase but there is no relevant experimental evidence to support this interpretation. Contamination by wall rock assimilation was proposed for chromitite formation in the Muskox (Irvine, 1975) and Kemi (Alapieti et al.. 1989) layered intrusions because alkali-rich inclusions occur in chromites from these bodies. Other models focus on migration of melts from the silicate-chromite cotectic into the primary phase volume of chromite. Ulmer (1969) and Murck and Campbell (1986) emphasized the importance of oxygen fugacity in the crystallization of chromite, and Cameron and Desborough (1969) suggested that contamination of the magma by gaseous emanations from the country rock could increase its oxygen fugacity, leading to the formation of monomineralic chromite horizons. Cameron (1980) subsequently abandoned this hypothesis in favor of chromite crystallization in

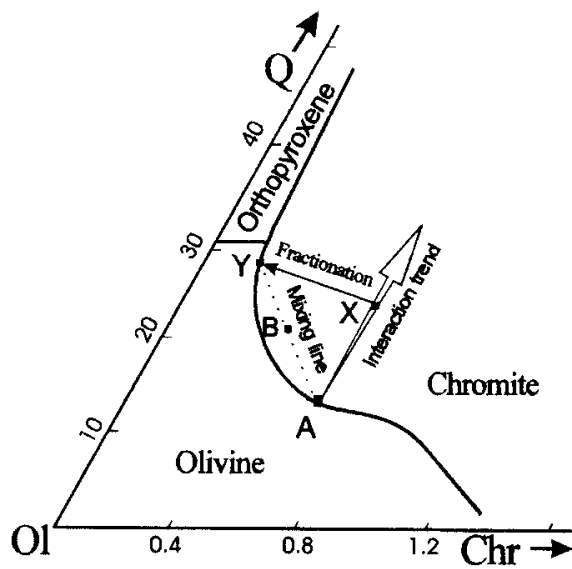

Figure 4 Phase relations in the system olivine-quartz-chromite as determined by Irvine (1977). A primitive magma (A) on the olivine-chromite cotectic would react with the peridotite host to form a range of more silicic compositions along a line such as $A$ $X$, all of which lie in the chromite field. Precipitation of chromite would drive the melts along lines parallel to $X Y$, moving them again toward the olivine-chromite cotectic. Batches of new mafic melt with a composition similar to $A$ could mix with the fractionated magma along a line such as AY, thus moving it again into the chromite field. (after Zhou, et al., 1996). response to changes in total pressure, a mechanism also invoked to explain chromite layers in the Stillwater complex (Lipin, 1993). However, the magnitude of the pressure change required to form a 1 m-thick chromitite layer would be unrealistically large (>l kbar) and, in general, the effect of pressure on mineral stability is smal? (Hatton and von Gruenewaldt, 1987: Campbell and Murck, 1993). The presence of chromitite layers in stratiform mafic intrusions strongly supports the interpretation that the parental magmas are basaltic in composition. Irvine (1977) and Irvine and Sharpe (1986) suggested that chromite precipitation from mafic melts in stratiform intrusions could be triggered by mixing of evolved and primitive magmas. This model is supported by textural evidence for common cotectic crystallization of chromite and olivine and is compatible with the observed sequence of layers in stratiform complexes (Sharpe and Irvine, 1983; Irvine and Sharpe, 1986; Murck and Campbell, 1986; Roeder and Reynolds, 1991; Campbell and Murck, 1993). We have used a modified version of Irvine's model to explain the precipitation of podiform bodies (Zhou and Robinson, 1994; Zhou et al., 1996).

Most podiform chromitites have dunite envelopes which grade outward into harzburgite or lherzolite. These envelopes are believed to have formed by melt-rock reaction in the same manner as dunites around many dikes in peridotite (Dick, 1977; Quick, 1981; Bodinier et al., 1990, Kelemen, 1990; Kelemen et al., 1992; Kelemen and Dick, 1995; Dick and Natland, 1995; Edwards and Malpas, 1995). As batches of relatively primitive, mafic magma rise through the host peridotite, pyroxenes are dissolved from the wall rock, leaving behind a dunite residue a few centimeters to a few meters thick.

The characteristic occurrence of dunite envelopes around podiform chromitites suggests a genetic relationship between the two. Removal of pyroxenes from the host peridotite by melt rock reaction would increase the silica content of the magma as demonstrated by experimental results (Fisk, 1986; Kelemen et al., 1990). Such an increase in silica would move the melts from the olivine-chromite cotectic into the primary phase field of chromite (Figure 4).

Once the melt has moved into the chromite stability field and chromite starts to precipitate, the melt would migrate toward the olivine-chromite cotectic, where olivine and chromite would again precipitate together (Figure 4). Batches of new magma rising through the conduit would mix with the fractionated melts, moving them back into the chromite stability field.

The interplay of melt-rock reaction, chromite fractionation and magma mixing would lead to many fluctuations in melt composition, producing both massive and disseminated chromitites and phase layering within a single podiform body. Continuous melt-rock interaction would result in the precipitation of chromite alone to form massive ores. If the magmas and host rock reached equilibrium and interaction ceased, chromite and olivine would precipitate together to form disseminated ores. Nodular ores probably form by a combination of chromite precipitation and convective overturn of the magma pocket.

\section{Tectonic setting of podiform chromitites}

The abundance of volatile- and alkali-rich mineral and fluid inclusions in chromite grains (Johan et al., 1983; McElduff and Stumpfl, 1991 ) indicates relatively high water contents in the parental magmas which, in turn, suggests formation in a supra-subduction zone environment. In such an environment $\mathrm{H}_{2} \mathrm{O}, \mathrm{K}_{2} \mathrm{O}$-rich fluids, and possibly silicate melts derived from the subducted slab can be added to the overlying mantle wedge (Ringwood, 1974; Pearce et al., 1984; Roberts, 1988). The melts from which chromitites precipitate are typically boninitic or tholeiitic with island arc characteristics (e.g., Malpas and Robinson, 1987; Roberts, 1988; Yumul and Balce, 1994; Zhou et al., 1996).

We suggest that podiform chromitites occur primarily in suprasubduction zone mantle sections and that their chemical compositions can be correlated with formation in different tectonic settings, 
specifically island arcs and nascent spreading centers, such as back arc basins (Zhou and Robinson, 1994).

Beneath island arcs, there is a high input of volatiles from the subducted slab into the overlying mantle wedge, leading to high degrees of partial melting and the formation of boninitic or highly depleted tholeiitic melts. In these environments, the old lithospheric mantle immediately beneath the crust would be invaded by large volumes of melts generated at depth by melting of depleted harzburgites (Figure 5). The new magmas would rise through and react with the old mantle, producing pods of high- $\mathrm{Cr}$ chromitite with dunite envelopes. Little spreading would be expected in such environments and the melts would tend to pond in the upper mantle. thus enhancing melt-rock interaction. If spreading did occur, the old lithospheric mantle would be thinned and eventually removed.

However, some podiform chromitites could still form by melt/rock reaction because melt compositions in these environments may also change with time. For example, in the Troodos ophiolite of Cyprus, the melts became increasingly depleted with time, changing in composition from relatively enriched andesites and dacites, to depleted tholeiites, to highly depleted boninites (Robinson et al., 1983). Such depleted melts presumably form at depth either by increased degrees of partial melting or by remelting of a progressively depleted source (Crawford et al., 1989 and references therein). As the melts separate from their source rocks and move upward through the mantle they are no longer in equilibrium with their host rocks and would react with them.

Ophiolites formed in such environments would be characterized by depleted mantle peridotites produced by high degrees of partial melting. The magmas from which the chromitites crystallized would be more refractory than the host peridotites and would react strongly with them, producing high-Cr chromitites and cumulate sequences of pyroxenite and gabbro. Such bodies would be similar to Papua-type ophiolites that contain low-Al tholeiites, Opx-cumulates and Cpx-free harzburgites (Ishiwatari, 1985).

In nascent spreading centers, such as those in back-arc basin, melts would still be generated in mantle wedges above subduction zones but less volatiles are added to the wedge and the degree of par- tial melting is lower. The lower degrees of partial melting will produce less depleted magmas from which high-Al chromites crystallize (Zhou and Robinson, 1994: Yumul and Balce, 1994). Melts generated by partial melting will rise into pre-existing, lithospheric mantle which is thinned during spreading (Figure 5). As the melts pass through the upper asthenospheric and lithospheric mantle they will react with the wall rocks, and precipitate high-Al chromitites. However. these melts are not as far out of equilibrium with their host rocks as those beneath island arcs and less reaction will take place.

The residual peridotites formed in this environment would be moderately depleted Cpx-bearing harzburgites or Iherzolites, similar to those of the Yakuno-type ophiolites which are characterized by high-Al tholeiite, and Cpx-type cumulates (Ishiwatari, 1985). Such bodies are similar to MORB ophiolites as defined by Pearce et al. (1984).

High-Al chromitites are associated with troctolite dikes (Figure 1A) that show a crystallization sequence of plagioclase before clinopyroxene (Thayer, 1969: Zhou and Robinson, 1994). Gabbros dredged from the Garret Fracture Zone and troctolites in the mantle of the East Pacific Rise have a similar crystallization sequence which has been explained by formation at relatively low pressures compared to pyroxenite dikes (Elthon, 1979; Hebert et al., 1983; Edwards and Malpas, 1995). Pyroxenite dikes associated with high$\mathrm{Cr}$ chromitites indicate high pressure crystallization from a high- $\mathrm{Mg}$ basaltic magma (c.f., Casey et al., 1983; Elthon. 1989). Thus, the associated mafic dikes are consistent with the proposed tectonic scenario for high- $\mathrm{Cr}$ chromitites beneath island ares and high- $\mathrm{Al}$ equivalents in back arc basins (Figure 5 ).

In New Caledonia high-Cr and high-Al chromitites, hosted in harzburgite and therzolite, respectively, are closely associated along a paleotransform fault (Leblanc, 1995). We suggest that such occurrences reflect formation in a fore-arc environment where hot astenoshpere rising along transform faults as subduction is inititiated (Stern and Bloomer, 1992; Malpas et al., 1997).

Beneath mature spreading centers, such as those of mid-ocean ridges, pre-existing lithospheric mantle is thinned and removed during spreading (Figure 5) and MORB magmas remain remarkably

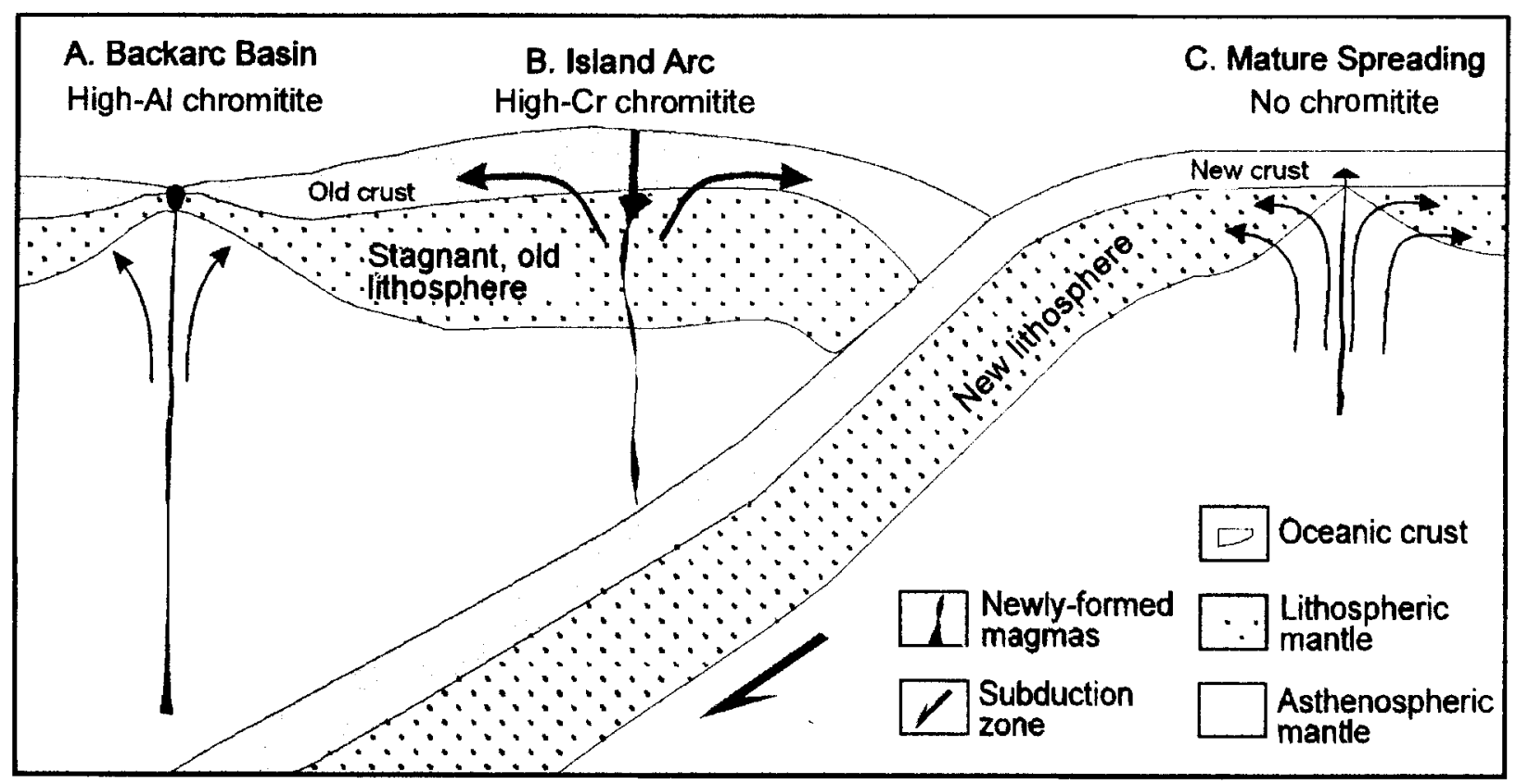

Figure 5 A diagram illustrating proposed relationships between tectonic environments and the formation of podiform chromitites of different composition (after Zhou and Robinson, 1997) Beneath island arcs there are thick sections of old, stagnant lithosphereic mantle in which rising melts can pond. The addition of water and other volatiles to the mantle wedge beneath the arc will enhance melting, leading to the production of highly depleted melts. These melts will react with the host peridotites to form abundant podiform chromitites rich in chromium. In back arc basins lower degrees of partial melting produce tholeiitic magmas from which high-Al chromitites crystallize. In this environment, the lithosphere is thinned and eventually removed by spreading so melt-rock interaction is most pronounced in the early stages of spreading. Beneath mature spreading centers, such as mid-ocean ridges, there is no old lithospheric mantle and the MORB melts are equilibrated with the peridotites through which they pass. Thus, no reaction takes place and no chromitites are produced. 
constant through time. Thus, magmas formed at depth would be relatively equilibrated with the wall rocks through which they pass and little reaction would take place. Because the magma compositions would not be modified significantly by melt/rock reaction, no large chromitite bodies would form.

\section{Conclusions}

Podiform chromitites form in the upper parts of ophiolitic or island arc mantle by reaction between rising melts and the host peridotites. $\mathrm{High}-\mathrm{Cr}$ chromitites form beneath island arcs where refractory melts, formed by relatively high degrees of partial melting, react with thick sections of old lithospheric mantle. High-Al varieties form in nascent spreading centers, such as back-arc basins, where less refractory melts react with thinned lithospheric mantle. No chromitite bodies would be expected beneath mature spreading centers, such as mid-ocean ridges, because there is no old lithospheric mantle and the rising melts are equilibrated with the depleted peridotites through which they pass.

\section{References}

Alapieti, T. T., Kujanpaa, J., Lahtinen, J. J., and Papunen, H., 1989. The Kemi stratiform chromitite deposit, Northern Finland: Economic Geology, v. 79, pp. 1057-1077.

Arai, S, 1980, Dunite-harzburgite-chromitite complexes as refractory residue in the Sangun-Yamaguchi zone: Western Japan Journal of Petrology, $v$ 21. pp. 141-165.

Arai. S.. 1992, Chemistry of chromian spinel in volcanic rocks as a potential guide to magma chemistry: Mineralogical Magazine v. 56. pp. 173-184

Auge. T. 1987. Chromite deposits in the northern Oman ophiolite: mineralogical constraints: Mineralium Deposita, v. 22. pp. 1-10.

Bodinier, J. L.. Vasseur. G., Vernieres, J., Dupuy, C., and Fabries, J., 1990 Mechanisms of mantle metasomatism: geochemical evidence from the Lherz orogenic peridotite: Journal of Petrology, v. 31. pp. 597-628.

Brown, M. A., 1980, Textural and geochemical evidence for the origin of some chromite deposits in the Oman ophiolite, in Panayiotou. A., ed. Ophiolites. Proceedings of the International Ophiolite Symposium. Cyprus, pp. 714-721.

Cameron, E. N., 1980, Evolution of the lower critical zone, centre sector. eastern Bushveld complex: Economic Geology, v. 75, pp. 845-871.

Cameron, E. N., and Desborough. G. A., 1969, Occurrence and characteristics of chromite deposits-eastern Bushveld complex, South Africa: Economic Geology Monograph 4, pp. 23-40.

Campbell, I. H., and Murck, B. W., 1993, Petrology of the G and H chromitite zones in the Mountain View Area of the Stillwater complex, Montana: Journal of Petrology, v. 34, pp. 291 v316.

Casey, J. F., Karson, J. A.. Elthon, D., Rosencrantz, E., and Titus. M.. 1983. Reconstruction of the geometry of accretion during formation of the Bay of Islands ophiolite complex: Tectonics. v. 2, pp. 509-528.

Cassard, D., Moutte, J., Nicolas, A., Leblanc, M., Robinovitch. M., Prinzhofer, A., and Routhier, P., 1981, Structure classification of chromite pods from New Caledonia: Economic Geology, v. 76. pp. $805-831$

Crawford. A. J., Falloon, T. J., and Green, T. H., 1989. Classification. petrogenesis, and tectonic setting of boninites, in Crawford, A. J., ed. Boninites and related rocks: London. Unwin Hyman. pp. 1-49.

Dick. H. J. B., 1977. Evidence of partial melting in the Josephine peridotite. in Dick, H. J. B, ed, Magma Genesis: Oregon Department of Geology and Mineral Industries Bulletin, v. 96, pp. 59-62

Dick. H. J. B.. and Bullen, T., 1984, Chromian spinel as a petrogenetic indicator in abyssal and alpine-type peridotites and spatially associated lavas: Contribution to Mineralogy and Petrology, v. 86, pp. 54-76.

Dick, H. J. B., and Natland, J. H., 1995, Late-stage melt evolution in the shallow mantle beneath the East Pacific Rise in Mevel, C. Gillis. K. M. Allan. J. F. and Meyer. P. S., eds., Proceedings of the Ocean Drilling Program, Scientific Results, v. 147, pp. 103-134.

Edwards, S. J., and Malpas, J. G., 1995, Multiple origins for mantle harzburgites: examples from the Lewis Hills massif, Bay of Islands ophiolite. Newfoundland: Canadian Journal of Earth Sciences, v. 32, pp. 1046-1057.
Elthon. D., 1979. High magnesia liquids as the parental magma for ocean floor basalts: Nature, v. 278, pp. 514-518.

Elthon, D., 1989, Pressure of origin of primary mid-ocean ridge basalts: Gological Society of London Special Publication No. 42, pp. 125-136.

Fisk, M. R.. 1986, Basalt-magma interactions with harzburgite and the formation of high magnesium andesites: Geophysics Research Lettets. v. 13. pp. $467-470$.

Grecnbaum, D., 1977. The chromitiferous rocks of the Troodos ophiolite complex: Economic Geology, v. 72, pp. 1175-1194.

Hatton, C. J., and von Gruenewaldt, G., 1987. The geological setting and petrogenesis of the Bushveld chromitite layers, in Stowe, C. W. ed, Evolution of Chromium Ore Fields: New York, Van Nostrand-Reinhold, pp. $109-143$.

Hebert. R..Bideau. D.. and Hekinian, R., 1983, Ultramafic and mafic rocks from the Garrett Transform Fault near $13^{\circ} 30^{\circ} \mathrm{S}$ on the East Pacific Rise: Igneous petrology: Earth and Planetary Science Letters. v. 65, pp. 107-125.

Hock, M., Friedrich, G., Pluger, W. L., and Wichowski, A.. 1986, Refractory and metallurgical -type chromite ores. Zambale ophiolite, Luzon, Phillipines: Mineralium Deposita, v. 21. pp. 190-199.

Irvine. T. N., 1967. Chromium spinels as a petrogenetic indicator. II, Petrologic applications: Canadian Journal of Earth Sciences, v. 4, pp. 71-103.

Irvine, T. N.. 1975. Crystallization sequences in the Muskox intrusion and other layered intrusions-II. Origin of chromite layers and similar deposits of other magmatic ores: Geochimica et Cosmochimica Acta, v. 39, pp. $991-1020$.

Irvine, T. N., 1977, Origin of chromite layers in the Muskox intrusion and other intrusions: a new interpretation: Geology, v. 5, pp. 273-227.

Irvine, T. N.. and Sharpe, M.R., 1986. Magma mixing and the origin of stratiform oxide ore zones in the Bushveld and Stillwater complexes, in Gallagher, M. J., Ixer. R. A.. Neary, C. R., and Prichard, H. M.. eds, Metallogeny of Basic and Ultrabasic Rocks: London. Institute of Mining Metallurgy. pp. 183-198.

Ishiwatari. A., 1985, Igneous petrogenesis of the Yakuno ophiolite (Japan) in the context of the diversity of ophiolites: Contributions to Mineralogy and Petrology, v. 89. pp. 155-167.

Jaques, A. L., and Green. D. H., 1980, Anhydrous melting of peridotite at 0$15 \mathrm{~kb}$ pressure and the genesis of tholeiite basalts: Contributions to Mineralogy and Petrology, v. 73, pp. 287-310.

Johan, Z., Dunlop, H., Le Bel, L., Robert, J. L., and Volfinger, M., 1983, Origin of chromite deposits in ophiolitic complexes: evidence for a volatileand sodium-rich reducing fluid phase: Fortschrung Mineralogie, v. 61. pp. 105-107.

Kelemen, P. B., 1990, Reaction between ultramafic rock and fractionating basaltic magma I. Phase relations, the origin of calc-alkine magma series, and the formation of discordant dunite: Journal of Petrology, v. 31, pp. $51-98$.

Kelemen. P. B., and Dick, H. J. B. 1995. Focused melt flow and localized deformation in the upper mantle: juxtaposition of replacive dunite and ductile shear zones in the Josephine peridotite, SW Oregon: Journal of Geophysical Research. v. 100. pp. 423-438.

Kelemen, P.B.. Dick. H.J.B., and Quick, J.E., 1992. Formation of harzburgite by pervasive melt/rock reaction in the upper mantle: Nature, v. 358, pp. 635-641.

Lago. B., Rabinowicz, M., and Nicolas. A., 1982. Podiform chromite ore bodies: a genetic model: Journal of Petrology, v. 23, pp.103-125.

Leblanc, M. 1987, Chromite in oceanic arc environment: New Caledonia, in Stowe, C. W.. ed, Evolution of Chromium Ore Fields: New York. Van Nostrand-Reinhold, pp. 265-296.

Leblanc, M., 1995, Chromitite and ultramafic rock compositional zoning through a paleotransform fault. Poum. New Caledonia: Economic Geology, v.90, pp.2028-2039.

Leblanc, M., and Ceuleneer, G., 1992. Chromite crystallization in a multicellular magma flow: evidence from a chromitite dike in the Oman ophiolite: Lithos, v. 27, pp. 231-257.

Lehmann. J., 1983, Diffusion between olivine and spinel: application to geothermometry: Earth and Planetary Science Letters, v. 64, pp. 123-138.

Lipin. B., 1993, Pressure increases. the formation of chromite seams, and the development of the ultramafic series in the Stillwater complex, Montana: Journal of Petrology. v. 34, pp. 955-976.

Lorand, J. P., and Ceulener, G., 1989, Silicate and base metal sulfide inclusions in chromite from the Maqsad area (Oman ophiolite, Gulf of Oman): A model of entrapment: Lithos, v. 22, pp. 173-190.

Malpas, J., and Robinson, P. T., 1987, Chromite mineralization in the Troodos ophiolite, Cyprus, in Stowe. C. W., ed, Evolution of Chromium Ore Fields: New York, Van Nostrand-Reinhold, pp. 220-237. 
Malpas, J., Robinson, P. T. and Zhou, M.-F., 1997, Chromitite and ultramafic rock compositional zoning through a paleotransform fault, Poum, New Caledonia: A discussion: Economic Geology 92, 502-504.

McElduff, B., and Stumpfl, E. F., 1991, The chromite deposits of the Troodos complex, Cyprus - Evidence for the role of a fluid phase accompanying chromite formation: Mineralium Deposita, v. 26, pp. 307-318.

Michael, P. J., and Bonatti,E., 1985, Peridotite composition from the North Atlantic: Regional and tectonic variations and implications for partial melting: Earth and Planetary Science Letters, v. 73, pp. 91-104.

Murck, B. W., and Campbell, I. H., 1986, The effects of temperature, oxygen fugacity and melt composition on the behaviour of chromium in basic and ultrabasic melts: Geochimica et Cosmochimica Acta, v. 50, pp. 1871-1887.

Mysen, B., and Kushiro, 1., 1977. Compositional variations of coexisting phases with degree of melting of peridotite in the upper mantle: American Mineralogist, v. 62, pp. 843-865.

Pearce, J. A., Lippard, S. J., and Roberts, S., 1984, Characteristics and tectonic significance of suprasubduction zone ophiolites, in Kokelar, B. P. and Howells, M. F., eds, Marginal basin geology: Geological Society London Special Publication No. 16, pp.73-95.

Quick, J.E., 1981, The origin and significance of large, tabular dunite bodies in the Trinity peridotite, Northern California: Contributions to Mineralogy and Petrology, v.78, pp. 413-422.

Ringwood, A. E., 1974, The petrological evolution of island arc systems: Geological Society London Journal, v. 130, pp.183-204.

Roberts, S., 1988, Ophiolitic chromitite formation: A marginal basin phenomenon?: Economic Geology, v. 83, pp.1034-1036.

Roberts, S., 1992. Influence of the partial melting regime on the formation of ophiolitic chromitite, in Parson, L.M., Murton, B.J., and Browning, P., eds, Ophiolites and Their Modern Oceanic Analogues: Geological Society of London Special Publication, No.60, pp. 203-217.

Robinson, P. T., Melson, W. G., O'Hearn, T., and Schmincke, H.-U., 1983. Volcanic glass composition of the Troodos ophiolite, Cyprus: Geology. v. 11, pp. $400-404$.

Roeder, P. L., Campbell, I. H., and Jamieson, H. E., 1979, A re-evaluation of the olivine-spinel geothermometer: Contributions Mineralogy and Petrology, v. 68, pp. 325-335.

Roeder, P.L., and Reynolds, 1., 1991, Crystallization of chromite and chromium solubility in basaltic melts: Journal of Petrology, v. 32, pp. 909-934.

Sharpe, M. R., and Irvine, T. N., 1983, Melting relations of the two Bushveld chilled margin rocks and implications for the origin of chromitite: Carnegie Institute of Washington Yearbook 82, pp. 295-300.

Stern, R. J., and Bloomer, S. H., 1992, Subduction zone infancy; examples from the Eocene Izu-Bonin-Mariana and Jurassic California arcs: Geological Society of America Bulletin, v.104, pp.1621-1636.

Thayer, T.P., 1964, Principal features and origin of podiform chromite deposits, and some observations on the Guleman-Soridag district, Turkey: Economic Geology, v. 59, pp. 1497-1524.

Thayer, T. P., 1969. Gravity differentiation and magmatic reemplacement of podiform chromite deposits: Economic Geology Monograph 4, pp. $132-146$.

Ulmer, G. C., 1969, Experimental investigation on chromite spinels: Economic Geology Monograh 4, pp.114-131.

Yumul, G. P., Jr., 1992, Ophiolite hosted chromite deposits as tectonic setting and melting degree indicators: examples from the Zambales Ophiolite Complex, Luzon, Phillipines: Journal of Research Geology (Mining Geology), v. 42, pp.5-17.

Yumul, G. P., Jr., and Balce, G. R., 1994, Supra-subduction zone ophiolites as favorable hosts for chromitite, platinum and massive sulfide deposits: Journal of Southeast Asian Earth Sciences, v. 10, pp. 65-79.

Zhou, M.-F., and Robinson, P. T., 1994, High- $\mathrm{Cr}$ and high-Al podiform chromities,Western China: Relationship to partial melting and melt/rock reaction in the upper mantle: International Geology Review, v, 36, pp. $678-686$

Zhou, M.-F., and Robinson, P.T., 1997, Origin and tectonic environment of podiform chromite deposits: Economic Geology, v.92, pp.259-262.

Zhou, M. F., Robinson, P. T., Malpas, J., and Li, Z., 1996, Podiform chromitites in the Luobusa ophiolite (southern Tibet): Implications for meltrock interactionand chromite segregation in the upper mantle: Journal of Petrology, v. 37., pp. 3-21.
Paul T.Robinson is Professor of Earth Sciences, at Dalhousie University, Halifax, Nova Scotia, Canada (currently Visiting Professor in the Department of Earth Sciences, The University of Hong Kong). He is also a member and former Director of the Centre For Marine Geology at Dalhousie University. He received his B.S. degree from the University of Michigan (1959) and his Ph.D. from the University of California, Berkeley (1964). His main research interests are ophiolites and ocean lithosphere and current projects include studies of the lower ocean crust in the Indian Ocean and of ophiolites in China.

Mei-Fu Zhou received his B. Sc. from Nanjing University, China (1983), M.Sc. degree from University of Saskatchewan (1992) and Ph. D. degree from Dalhousie University, Canada (1995). His main research interests focus on the geochemistry and metallogeny of mafic/ultramafic rocks. He is currently in the Department of Earth Sciences, University of Hong Kong, managing the departmental ICP-MS laboratory.

John Malpas is currently Professor and Head, Department of Earth Sciences, The University of Hong Kong. He received his M.A. from Oxford University (1971) and PhD from Memorial University of Newfoundland (1976). He has an extensive research programme investigating the genesis and tectonic setting of ophiolites, ocean island volcanics and aspects of environmental geochemistry. He has been involved for several years with the Ocean Drilling Program.

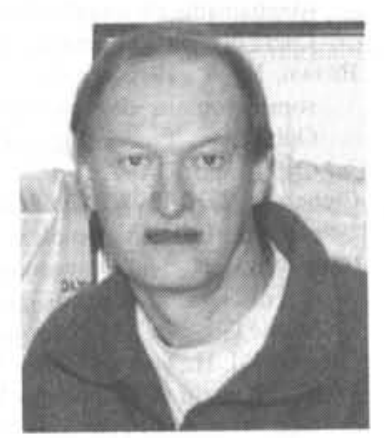

Wen-Ji Bai, graduated from Changchuan College of Geology, China (1958), has been a research professor in the Insititute of Geology, Chinese Academy of Geological Sciences, Beijing. His main research fields are ophiolites and their ore deposits and he has published over 80 papers and 5 monographs in Chinese. 